\title{
PSYCHIC DEPRIVATION IN SCIENTIFIC TERMS
}

\section{Terletska Yuliana ${ }^{1}$}

DOI: http://dx.doi.org/10.30525/978-9934-571-27-5_53

Abstract. The subject of this research work is psychic deprivation of a person. The methodological foundations of the study of psychic deprivation are the provisions on the dependence of mental states on the course of mental processes and the manifestation of mental properties and mental formations, the provisions on the regularities of the human psyche's functioning, on the dependence of the human's internal (psychic) on the external factors. The paper also speaks about the provisions on the functioning of the human psyche, which are presented in the energy conception of the psyche and the psychic. Namely, these provisions are about the human psyche as an independent individual holographic informational and energy formation; about the constant interaction of the psychoenergy of the external, the internal, and the internally internal psychic, as a result of which the external and internal worlds are reflected; about psy-programs as an instrument of operational and functional transformations and formations in the human psyche. The methods of analysis, synthesis, comparison, abstraction and grouping of the available knowledge about psychic deprivation, the human psyche, and its activities are used.

The objective of the scientific research is to identify how the notions of deprivation and psychic deprivation of a person are researched, to reveal and critically assess the approaches to their understanding and interpretation, to substantiate the essence and content of psychic deprivation from the standpoint of a psychic and functional approach. Seven approaches to the understanding and interpretation of deprivation and psychic deprivation of people are identified and substantiated, namely these are: the static psycho-permanent approach, deficiently-losing one, the approach of impoverished environment, deviant, negatively deterministic, of social exclusion, and psycho-emotional one.

It is proved that from the standpoint of the psychic and energetic functional approach, psychological deprivation of a person, in its essence, means

\footnotetext{
${ }^{1}$ Candidate of Psychological Sciences, Assistant Professor of the Department of Pedagogy and Social Management, Lviv Polytechnic National University, Ukraine 


\section{Terletska Yuliana}

a greater or lesser degree of violation of the capacity of the person's psyche in connection with the malformation, underdevelopment or destruction of certain mental parameters because of the subject's failure to satisfy certain needs necessary for normal livelihood and development. With regard to the reflection of structural changes in the psyche, psychic deprivation of a person is a change in the parameters of mental processes, mental properties, and mental formations, which reduces the operational and functional capacity of the psyche of the subject, that is, the quality, effectiveness of its functioning, in accordance with the age norms of psychosocial development. With regard to the functional state of the psyche, psychic deprivation is a stagnation, delay, inertia, rigidity, inhibition, failure of a person's psyche, in accordance with the age norms of psychosocial development, to adequately perform the operative and functional activity. With regard to the norm and deviation from it (non-normality), psychic deprivation of a person is an unnormalized process of functioning of the person's psyche, that is, the one that was not brought to norm, was not normalized in accordance with the signs and indicators that reflect the psychosocial development that is inherent in every age stage.

The reason behind the psychic deprivation of a person, which arises as a result of the failure to satisfy certain needs, lies in the fact of malformation and/or underdevelopment, and/or destruction of the parameters of mental processes, mental properties, and mental formations, which, in turn, leads to a decrease in the overall potential capabilities of the operational and functional psyche and its effectiveness. It is established that the reason for the emergence of the psychic deprivation of a person is the external deprivation conditions in which the person cannot satisfy the necessary needs, as well as the internal factors due to which the person voluntarily deprives himself/herself of satisfying the needs that are necessary for the person's development and vital activities, or requires the satisfaction of such needs which cannot be satisfied or can be satisfied only under certain circumstances. Psychic deprivation can be explicit or implicit (disguised). On the basis of the results of the scientific and theoretical, systematic and analytical search, we came to the conclusion that psychic deprivation is divided into the following types: psycho-sensory, psycho-emotional, psycho-physiological, psycho-cognitive, psycho-motor, psycho-social, psycho-economic, psycho-cultural, psycho-spiritual, and psycho-sexual. 


\section{Introduction}

The analysis of literary sources shows that in science there is no single definition of the essence and content of deprivation and psychic deprivation of a person. Most often, in psychology, psychic deprivation is interpreted as a mental state of a person, which arose as a result of various adverse impacts that occur in life situations. Here, undoubtedly, the results of the work of Czechoslovak scholars J. Laugmeier and Z. Matejcek "Psychological deprivation in childhood", which is the first fundamental work on the problem of psychological deprivation, are used as a basis [14]. However, the researchers did not take on the task to explain through evidence of the psychological viewpoint how psychological deprivation being a manifestation of the mental state influences human actions, behaviour, and vital activities. Apparently, psychic deprivation is a more complex mental phenomenon than a mental state. Even the mentioned first researchers of psychological deprivation J. Laugmeier and Z. Matejcek questioned the accuracy of their definition of psychological deprivation. They write, "In the definition, we are talking about a "mental state". We understand it not as something constant and permanent, but we do not know how to express the actual spiritual reality that arises through the corresponding specific process (caused in our case by a stimulating unification) and which is the basis or the internal mental condition of the corresponding specific behaviour (in our case - the deprivation consequences)" [14, p. 19-20]. Therefore, exploration of the real nature and content of psychic deprivation requires further research.

The objective of our scientific research is to identify the state of research of deprivation and psychic deprivation in science, to identify approaches to their understanding and interpretation, to carry out their analysis and to substantiate the essence and content of psychic deprivation of a person from the standpoint of a psychic and functional approach.

The tasks of the research are as follows: 1) to determine and evaluate the state of research of the problem of deprivation in science; 2) to identify the existing approaches to understanding and interpretation of deprivation and psychic deprivation of a person; 3 ) to reveal the essence and content of psychic deprivation of a person from the standpoint of a psychic and functional approach.

The methodological foundations of the study of psychic deprivation are the provisions on the dependence of mental states on the course of mental processes and the manifestation of mental properties and mental 
formations; the provisions on the regularities of the human psyche's functioning; on the dependence of the human's internal (psychic) on the external factors; the provisions on the functioning of the human psyche, set forth in the energy conception of the psyche and the psychic by M. Variy, namely on the human psyche as an independent individual holographic informational and energy formation; on the constant interaction of the psychoenergy of the external, the internal, and the internally internal psychic, as a result of which the external and internal worlds are reflected; on psy-programs as an instrument of operational and functional transformations and formations in the human psyche. The following methods were used for the realization of the tasks: the methods of analysis, synthesis, comparison, abstraction and grouping of the available knowledge about the human psyche, its operational and functional activity, about the psy-programs as an instrument of transformation and formations in the psyche, about the influence of the environment as the external psychic on the development and functioning of the human psyche.

\section{Current state of research of the problem of deprivation}

In order to identify and assess the state of research of the problem of psychic deprivation of a person in science, first of all, it is necessary to establish the origin of the term "deprivation". According to the dictionaries, this term comes from the English word deprivation meaning a lack, loss of something due to a failure to satisfy some important need. The stem of the word consists of a Latin root privare, which means to "separate". The prefix $d e$ in the English word emphasizes the meaning of the root (for example, Latin prressare - meaning "press", "push", derressio - meaning "suppress" and English depress and depression). Among those who were the first to use these words were Z. Freud and R. Spitz in their descriptions of the manifestations of maternal deprivation [29]. Thus, the word started being used as a scientific term, which they used to talk about the situation of a sudden weaning, as a result of which in the life of the child such changes that had devastating consequences for his/her personality appeared.

However, for a long time, the concept of "deprivation" was absent from both foreign dictionaries and domestic ones. In our opinion, one of the first foreign works in which deprivation is considered as a serious multifaceted psychological problem is the above-mentioned work of J. Laugmeier and Z. Matejcek [14], which was published in Russian in the USSR in 1984. In 


\section{Psychic deprivation in scientific terms}

this paper, alongside with the concept of deprivation, the researchers also point out other related to it terms, such as psychological starvation, mental deficiency, mental exhaustion [14, p. 17]. They distinguish such concepts as "deprivation" and "frustration", "deprivation" and "conflict" and also argue that deprivation is a much more serious and difficult "psychophysiological state" than frustration and conflict.

As for the former USSR, the post-Soviet countries, for the first time this concept was defined in the article of the "Russian Pedagogical Encyclopedia" edited by V. Davydov, published in 1993, dedicated to the issue of child deprivation [26]. In Ukrainian publications, deprivation as a psychological problem was first discussed only at the beginning of the twenty-first century, for example, in the psychological encyclopedia, whose author and compiler is O. Stepanov [23, p. 18].

In order to reveal the state of research of the problem of deprivation, we shall analyse the views of scientists on its types. Thus, by the beginning of the twenty-first century, researchers had identified and described only sensory, emotional, semantic (cognitive), and social deprivation, drawing on the studies of J. Laugmeier and Z. Matejcek who identified: 1) stimulus (sensory) deprivation, which manifests itself in the reduction of a number of sensory stimuli or in their limited variability and modality; 2) deprivation of meanings (cognitive) as an overly changing, chaotic structure of the external world without a clear order and content, which does not allow understanding, anticipating and regulating what is happening outside; 3) deprivation of emotional attitude (emotional) as an insufficient possibility of establishing an intimate emotional attitude to a person or a breaking of such an emotional connection if it has been established before; 4) deprivation of identity (social), which lies in limiting the possibilities for assuming an autonomous social role [14].

Sensory deprivation, which is viewed by the majority of scholars from the point of view of a lack, is the most fully described in psychological literature. It is interpreted as "a long, more or less complete person's deprivation of sensory impressions, which is carried out for experimental purposes" [12, p. 142]. Virtually the same definition is given in a number of dictionaries and in the Russian psychological encyclopedia, edited by R. Corsini and A. Auerbach [22, p. 796]. While in the Ukrainian psychological encyclopedia (author and compiler O. Stepanov), the essence of sensory deprivation is defined as "a long-lasting 


\section{Terletska Yuliana}

full or partial deprivation of human sensory impressions carried out as part of experiment" [23, p. 97].

The Great Psychological Dictionary, edited by B. Meshcheryakov and $\mathrm{V}$. Zinchenko, provides a definition for the term of "sensory isolation". It says, "Sensory isolation is the state when an organism is kept in the conditions of exclusion from its environment of as many irritants as possible". However, clarification of this concept shows that we are talking about sensory deprivation here [3, p. 500].

Some researchers equate the term of "sensory deprivation" with the term "sensory hunger", indicating the absence or the lack of emotional connections. Thus, E. Berne concludes that, "the lack of emotional connections can have fatal consequences for a person. These observations confirm that there is a sensory hunger and a need in a child's life for the stimuli that provide the child with physical contact" $[2$, p. 6]. At the same time, E. Berne connects the lack of sensory impressions with a negative mental state and mental disorders.

Incidentally, the above-mentioned sources actually speak of sensory deprivation, more rarely - of emotional deprivation, and only a few works mention social and cognitive kinds of deprivation. Other types of psychic deprivation are not identified and explored by scientists. Meanwhile, some authors equate or approximate the concept of "deprivation" with the concept of "separation", "isolation".

Thus, on the basis of the analysis of foreign and domestic literature dedicated to the problem of deprivation and psychic deprivation, we state, first of all, that today scientists more often use the term "deprivation" rather than the term "psychic deprivation", and the semantics of these concepts often depends on the conceptual and theoretical position of the author. Secondly, there is no distinction between the concepts of "deprivation of a person" and "psychic deprivation of a person". Thirdly, the psychic peculiarities of manifestation and the influence of the actual psychic deprivation on the development, behaviour, and activities of a person are not revealed. Fourthly, the concepts of "deprivation mechanisms", "deprivation situations", "form of deprivation", "deprivation conditions", "deprivation process", as well as their subordination and interdependence are used but not clearly distinguished. Fifthly, it is not clearly known how deprivation conditions are reflected in the human psyche, to what changes in it they lead, etc. 


\section{Analysis of the approaches to the interpretation of deprivation}

A comprehensive study of literature shows that science has developed different approaches to understanding and interpretation of deprivation (psychic deprivation) of a person.

The first and the most widespread of these approaches is the static psycho-permanent, whose representatives consider deprivation and psychic deprivation as a mental state arising from the dissatisfaction of needs, drawing on the results presented by J. Laugmeier and Z. Matejcek in their work [14]. One of its main conclusions is as follows, "Psychological deprivation is a mental state that arose as a result of such life situations in which the subject is not given the opportunity to satisfy some of his basic (vital) mental needs to a sufficient extent and for a sufficiently long time" [14, p. 19].

This is the definition of psychic deprivation given in the Ukrainian psychological encyclopedia, the author and compiler of which is O. Stepanov [23, p. 18]. At the same time, among the "basic (vital)" needs there are the following ones: "1) the need for a certain amount, variability, and variety (modality) of stimuli; 2) the need for the basic conditions for meaningful learning; 3) the need for primary social relations (especially with the mother), which ensures the possibility of active basic integration of an individual; 4) the needs of social self-realization, which provides the opportunity to master various social roles and gain valuable goals" [23, p. 20].

The fact that deprivation (actual deprivation, not psychic deprivation-au-thor's note) is a mental state is also indicated by modern Ukrainian researchers Ya. Hoshovskyi [9, p. 109] and A. Masliuk [20]. For example, the latter writes, "We understand the phenomenon of deprivation as a mental state that arises as a result of limiting the possibility to satisfy basic mental and personal needs" [20, p. 63].

As we see, this definition is about "limiting the possibility to satisfy basic mental and personal needs,» but it does not explain what this limiting means and how it is represented in the human psyche.

The author then describes the effects of some types of deprivation. Thus, with regard to physiological deprivation, he writes, "The physiologically deprived personality that exists within a closed environment which blocks the main vital needs, might have the most important components of his/her psychological structure shifted and modified, which results in anti-social behavioural tendencies. The motivation of such a person is reduced to the primitive needs, the vital need for food" [20, p. 89]. 


\section{Terletska Yuliana}

In our opinion, first of all, even physiologically deprived personalities do not always have "the most important components of his/her psychological structure shifted and modified"; moreover, they do not always cultivate "antisocial behavioural tendencies". For example, voluntary fasting of hermits, monks, patients for the purpose of treatment, forced starvation of the inhabitants of the settlements under the enemy's siege, and so on. If the most important components of the psychological structure of the deprived personality do shift and modify, then this, first of all, means that they are in any case primary with respect to a particular mental state of a person.

However, a question arises as to how the influence of these modified "psychological structures" on the formation of a particular mental state is exercised? Is it only the psychic deprivation that influences its formation? Assuming that it is only the psychic deprivation that causes a particular mental state, then it turns out, for example, that in the case of a child being raised without parents, it lasts for life? Then again, a question arises: what is the content of this "permanent" mental state?

In our opinion, psychic deprivation does not directly affect a particular mental state of the subject, which means that it cannot be interpreted as a mental state.

Let us prove this.

It is worth emphasizing that there are many works dedicated to the mental state of a person, its interpretation, emergence and manifestation in various conditions. First of all, we shall note that mental states of people have relatively recently become the object of profound scientific research (since the publication of the book by N. Levitov "On the mental states of man" [15] in 1964). However, so far, despite the fact that a considerable scope of empirical materials has been accumulated, many theoretical questions regarding the phenomenology of mental states remain with no answers. The reason for this is that for a long time there was a discrete approach to mental life, in accordance with which, mental processes, mental properties, and mental formations of a personality were viewed separately from mental states; that is, between them, interdependencies and interdeterminations of systemic and synergetic nature were not established. However, to date, it has been proved that mental states of people arise in the result of an interaction of mental processes, which unfold over a certain period of time, with their mental properties and mental formations [5; 18 and others]. 


\section{Psychic deprivation in scientific terms}

Here it should be noted that the term of "mental formation" is not commonly used now. But, in our opinion, in relation to the effect on the emergence of a mental state it is more appropriate than the term "individual features", since the latter, as emphasized by S. Maksymenko, refers to mental processes, mental properties and mental states [18], as well as to mental formations, in our opinion, which is also pointed out by the aforementioned author $[18$, p. 6$]$.

Generally, discussions about mental formations as the equivalent components of the psyche of an individual started a long time ago. For example, in 1981, a Russian researcher M. Fedenko when studying the structure of the human psyche indicated that it "consists of such components as mental processes, properties, states, and formations." He reckons knowledge, abilities, skills, and habits among mental formations, emphasizing that they "are enriched and developed throughout life" [28, p. 9-10]. The idea of mental formations gained further development in the works of various Ukrainian scholars, including S. Maksymenko [18], M. Variy, who, for example, explains that "mental formations are shaped in the process of education and socialization of an individual. The author reckons motives, stereotypes, beliefs, mindset, knowledge, skills, abilities, etc. among them [5, p. 241].

And this is correct! Hence, N. Levitov emphasized, "The definition of a mental state as a special psychological category is understood as follows it is a holistic characteristic of mental activity over a certain period of time, which shows the peculiarities of the course of mental processes, depending on the objects and phenomena of reality that are reflected, the previous state and the mental properties of the personality" [16, p. 31]. This implies that a mental state of a person appears on the basis of the peculiarities of the course of his/her mental processes that interact with the mental properties and the previous mental state.

Later on, N. Levitov makes several important reservations, which confirm our opinion once again, namely: 1. "There are no mental states beyond mental processes, and there can be none." 2. "Mental states are closely linked with individual peculiarities of a personality." 3. "The general is that mental states and individual characteristics reflect the individual and synthetic characteristics of the mental activity, and not just the characterization of its individual elements, functions or sides" [16, p. 32].

S. Maksymenko provides a detailed description of mental states. He writes: 1) "Mental states are a psychological characteristic of an individ- 


\section{Terletska Yuliana}

ual, which reflects his/her relatively long-lasting stressful experiences..."; 2) "Mental state is a concept used to conditionally mark relatively static, permanent elements in the psyche." And then, "Unlike the concept of "mental process", which emphasizes the dynamic elements of the psyche, and the concept of "mental property", which indicates the duration of manifestations of the human psyche, mental states are determined by their fixedness and repeatability in the structure of the human psyche" [19, p. 56]. In his other work, S. Maksymenko emphasizes, "A true understanding of the nature of mental states lies, in our opinion, not in the study of the states as such and their systematization, but in the analysis of their dynamics, development, and relationships with other psychic phenomena. It has been mentioned before that a mental state is a concentrated and synthetic reflection of all psychological features of a personality" [18, p. 200].

We can support S. Maksymenko's point of view that "mental states are determined by their fixedness and repeatability in the structure of the human psyche" only in the context of his previous statement, "Mental state is a concept used to conditionally mark relatively static, permanent elements in the psyche" $[19$, p. 56]. We believe that no mental state is "fixed" in the structure of the psyche, like mental properties or mental formations for example, and its repeatability only lies in the fact that it is present and it reflects the nature of the interaction of the current mental processes with mental properties and mental formations. Otherwise, such a mental state turns into a mental property or an individual peculiarity.

On this basis, we can conclude that in relation to mental processes, mental properties, and mental formations, mental state is a reflection of their integrated impact at a certain period of time. This is confirmed, for example, by M. Variy, according to whose views, "mental states emerge during the overlay of psy-energy of current mental processes on the properties and mental formations of a person" [5, p. 241].

Consequently, psychological deprivation is indirectly connected with the mental state of the deprived personality. First of all, it causes a change in the parameters of the psyche of the individual (mental processes, mental properties, and mental formations), while the latter together with other factors influence the formation of this or that mental state of the person.

A definite mental state of a person depends on the mental processes that are currently taking place and are superimposed on the person' mental properties and mental formations. Therefore, under one and the same depri- 


\section{Psychic deprivation in scientific terms}

vation conditions, the mental state of an individual may be different. For example, two children are outcasts in the school, that is, they are both in the same deprivation conditions, but one child falls into depression, refuses to go to school, cries, suffers, asks parents to move him/her to another school (there are even cases of suicides on this basis); and the second child does not only resists his/her offenders, but also becomes aggressive, takes vengeance on them, abuses them as well.

Another example is that a monk who devoted himself to serving the God and secluded himself from people experiences different mental states than a criminal who is serving his sentence in a solitary confinement.

Thus, since psychic deprivation reflects changes in the parameters of mental processes, mental properties, and mental formations, they are, in fact, primary in relation to mental states.

The second approach is a deficiently-losing one, whose representatives point out that deprivation is the loss of someone or something or a lack of something. For example, the Great Psychological Dictionary edited by B. Meshchieryakov and V. Zinchenko writes, "Deprivation is a loss or approximate to it in terms of expression and meaningful for the subject lack of something necessary, desired" [3, p. 130].

However, here again, a number of questions arise: where does this "lack of something necessary, desirable" manifest itself - in the surrounding environment or in the human psyche? If it emerges in the surrounding environment, how does it transform into the human psyche? And does it always transform? How is it represented in the psyche? What does it change in the psyche? How does it influence the psyche's operational and functional activities, etc.?

Within this approach, A. Reber explains deprivation as a state of loss, as well as a separation of an object or person from something [24].

It is difficult to agree with such a statement. For example, the very loss (death) of a loved one is not a psychic deprivation, but a stress, a mental trauma, in the first place, which, by the way, can lead to deprivation conditions.

Another researcher D. Kun believes that "deprivation is a deficit or a refusal from normal stimulation, nutrition, comfort and love" [13, p. 115].

It is also difficult to agree with this statement, because these phenomena do not always grow into deprivation conditions. And how are they reflected in the human psyche? For example, a diet (refusal of normal nutrition) with an aim of reducing excess body weight cannot be equated to deprivation. 


\section{Terletska Yuliana}

The third approach - of impoverished environment - describes deprivation, using the notion of "impoverished environment" [21, p. 33], that is, the environment in which a person does not receive a sufficient amount of visual, auditory, tactile, emotional, social and other stimuli. At the same time, representatives of this approach point out that such an environment may accompany the development of a child, and also be included in the life situations of an adult.

For example, it is in the impoverished environment that the adherents of the cognitive direction see the reason behind the mental retardation of children. They point out that socially deprived children do not formulate "action strategies", by which we understand the rules necessary for effective decision-making and behaviour, and "environment models", which are formed as a result of its monotonous influences that are constantly repeated. As a result, children have difficulties in assessing situations, in transferring past experiences into new conditions, they fail to effectively solve problems.

Thus, in this context, the deprivation of a child (adult) is equivalent to deprivation conditions. Representatives of this approach mainly describe the impoverishment of the environment and the negative consequences of its influence on the development of a child and the behaviour of an adult, but do not reveal the changes that occur in the human psyche, in its operational and functional activities, etc. After all, psychic deprivation of a person is presented not externally, but in his/her psyche.

Representatives of the fourth - deviant - approach view deprivation and psychic deprivation as a deviation from the norms established at a certain period of development of society. Thus, according to E. Sergienko, "deprivation is a deviation from the environmental continuum, which is evolutionarily expected, characteristic of this species" [27, p. 152]. It allows for the presence of external and internal deprivation, by which the relevant conditions are meant.

Firstly, such deviations can be caused by completely different factors that are not related to psychic deprivation. Secondly, generally, they can be the result of psychic deprivation. But this approach does not reveal the deprivation operation and functional activity of the psyche, and those changes in it that resulted in its occurrence either.

L. Yadvirshis talks about various types of deprivation deviations from the standpoint of the fourth approach. Namely, she talks about cultural 
deprivation as an insufficient development of cultural needs, the presence of which is contemplated in modern civilization; cognitive deprivation as a lack of opportunities to understand and control what is happening around; social deprivation as a limitation of opportunities for the assimilation of an autonomous social role as a result of the lack of contacts with the external environment, micro- and macro-environment [30].

It is true that psychic and cultural deprivation being a form of psychic deprivation is present in the lives of some people. But it should be considered through the prism of changes in the functioning of the psyche, changes in its parameters, etc.

While person's lack of ability to understand and regulate what is happening around is not always a consequence of cognitive deprivation. This can also be the result of the absence of socialization, desocialization, maladaptation, etc. But the author does not give an answer to the question of how cognitive deprivation is represented in the human psyche, how it affect its operational and functional activities.

The fifth approach - negatively deterministic - points out that psychic deprivation means adverse impacts. Thus, in one of his works E. Rogov argues that the term "psychic deprivation" means various adverse impacts that occur in life situations" [25, p. 14].

First of all, here we are not talking about psychic deprivation, but only about deprivation conditions and their consequences. Secondly, the negative factors that carry out adverse impacts cannot be fully attributed to deprivation conditions. For example, a short-term extreme situation does not lead to psychic deprivation. It can cause stress, mental trauma, or the person might get off with nothing more than a little fright altogether. Constant quarrels in the family also have a negative impact on children, but this is not a psychic deprivation.

Representatives of the sixth approach - the approach of the social exclusion - view social deprivation as a complete absence of social contacts [1, and others]. However, here again, scientists describe the conditions, forms, and effects of isolation. Yet, whatever is going on in the psyche of the socially excluded person remains unknown.

Representatives of the seventh - psychic and emotional - approach consider deprivation from the standpoint of the lack of emotional ties $[10 ; 11$; 17, and others]. Thus, J. Bowlby in his monograph "Maternal Care and Mental Health" emphasized that deprivation is a situation in which the sub- 


\section{Terletska Yuliana}

ject suffers from an insufficiency of emotional ties that causes a number of mental health disorders of various degrees of resistance [cit. ex 10].

A. Freud interprets maternal deprivation through the prism of "separation anxiety", when the protest of small children against the absence of the mother reaches painful and psychologically destructive forms and parameters [cit. ex 17].

Meanwhile, B. Yerzhabkova understands the term of "deprivation" as a negative reaction of an adult (irritation and dissatisfaction) in various situations due to the lack of something" [11, p. 227].

In our opinion, here we can speak about psycho-emotional deprivation as a kind of psychic deprivation of a person. But individual cases of irritation, dissatisfaction, even anger are not a mental psychological, however, they can be its consequences.

Thus, on the basis of the results of the study of deprivation and psychic deprivation in science, we have identified different approaches to their understanding and interpretation, which were grouped on the basis of certain features, and gave the following names to these approaches, namely - static psycho-permanent, deficiently-losing, of impoverished environment, deviant, negatively deterministic, of social exclusion, and psycho-emotional.

Two essential features of the positions of researchers of deprivation and psychic deprivation were revealed. The first feature is that one part of the researchers view the concept of "deprivation" in the conceptual plan of psychological phenomenology as the main, determinant concept; and the second feature is the fact that it is actually psychic deprivation that is understood by deprivation. At the same time, definition of the essence of deprivation and psychic deprivation is narrowed down to their interpretation as either a mental state, or to the causes of their occurrence, and this interpretation is, in fact, equated to these causes, or to the consequences to which they lead.

\section{Essence of psychic deprivation of a person: psychic and energetic and functional approach}

The results of the study set forth above show that, no matter in what light scientists viewed deprivation and psychic deprivation, we believe, that they missed out the most important thing - the psyche of man, in which changes actually take place as a result of dissatisfaction of needs: development, its delay or regress, formation or destruction of certain parameters of the psy- 
che, etc., that is, the course of psychic deprivation. After all, psychological deprivation of a person is a phenomenon of his/her psyche, its derivative. It is the result of violations of the processes of the operational and functional activities of the psyche, which, in their turn, depend on the level of development, maturity, perfection of mental processes, mental properties, mental formations, and their components, which change under the influence of dissatisfaction of the corresponding needs.

Therefore, in order to reveal the essence of psychic deprivation of a person, which is a derivative of the person's psyche, its function - first of all, it is necessary to know how this psyche is represented, how it performs operational and functional activity.

Since nowadays, in the study of various mental phenomena, researchers rarely rely on any concept or model of the human psyche, but rather consider them separately, detached from it (which, according to M. Variy, is a mistake, since it is never possible to fully understand a separate mental phenomenon without the context of functioning of the entire psyche, just as it is impossible to understand the principles of movement without knowing whose movement it is - of a rocket, bullet, light, aircraft, turtle, wind, man, fish, etc.), we rely on the principles of psychic and energetic and functional approach presented in the energy conception of the psyche and the psychic by M. Variy [4; 7].

We will briefly outline the main theses of this conception.

Thus, the first one is the thesis on the psychic as a phenomenon which "contains psychoenergy of any polarity and can interact with the human psyche and other psychic" [7, p. 68]. Hence, the human psyche functions at the energy level, that is, in the form of a psy-energy, in which information of different content and its significance for the subject of the psyche is laid down. Such psy-energy (the psychic) contains two components: 1) informational component; 2) energy component. The informational component comprises the information about phenomena, processes, events, intentions, attitudes and so on. The energy component reflects the magnitude (the degree of significance of the content of information), that is, the energy capacity of the psychic. The energy capacity (its increase or decrease) actually depends on the importance of this information for the person, on how much and how deeply the person experiences it and believes in its realization. The degree of significance reflects the capacity of the psychic, the power of its influence on any other psychic, and therefore - on the actions and behaviour of the person. 


\section{Terletska Yuliana}

The psychic is divided into internal and external. Everything that concerns the inner world of an individual belongs to the internal psychic-emotions, feelings, experiences, images, states, properties, motives, values, attitudes, views, thoughts, stereotypes, various mental formations, and so on. Each of these phenomena exists in the psyche in the form of a mobile layer of independent psychic energy. The mentally-psychic, that is, what is inherited by an individual from its ethnic group and nation, belongs here as well.

The external psychic exists outside the individual and contains psychic energy and affects the individual's psyche. Such psychic energy can be uneven in both volume and polarity, and in relation to the impact on human behaviour and life activities it can be positive, neutral or negative. At the same time, when reproducing and transforming the external psychic, people embody it in their norms of behaviour, principles, emotions, feelings, customs, values, socio-psychological attitudes, relationships, activities, creativity, etc., that is, the external psychic can turn into the internal psychic [7, p. 68-69].

The second thesis says that "in essence and content, the human psyche is a relatively independent individual holographic informational and energy formation with its own psy-code, which stores the information about the past, present and future of the subject of the psyche, its inner and outer world, and also reflects their significance for the subject". The third thesis states that the human psyche has a multilevel and multisystem structure but holistic and independent formation, which exists simultaneously in the individual and outside him. The fourth thesis - in terms of operational and functional capabilities the human psyche is a process of constant interaction of the psychic energy of the external, the internal, and the internally internal psychic, which results in the reflection of the past development of mankind, race, ethnic group and nation, family, as well as the outside world; the maintenance and reproduction of the internal world of the subject of the psyche; harmonization and streamlining of the senses of his life, de-objectification of the internal psychic into the external one and the objectification of the external psychic into the internal one [7, p. 69-70].

The fifth thesis is about the fact that psy-programs are the instrument of the operational and functional transformations and formations in the human psyche. In this context, M. Variy writes, "We believe that these are the psy-programs of the human psyche that are an instrument for implementing operative and functional transformations of both the external and 


\section{Psychic deprivation in scientific terms}

the internal psychic on the basis of the existing psychic, its psycho-energy, its receptioning, processing, transformation and transmission" [6, p. 78]. The author then explains, "A psy-program is the internal psychic, formed on the basis of an unconscious or conscious fixed attitude with its psy-code, which activates another internal and/or external psychic, in accordance with this code, and directs it at the realization of the information laid down in the fixed attitude" [6, p. 78].

According to the views of M. Variy, the fixed attitudes "for the conscious (conscious level) or the subconscious (subconscious level) formation of psy-programs are actualized (activated) desires, images, purpose, convictions, different goals, faith, meaningfulness of life activities, ideas, obsessive thoughts, views, interests, stereotypes, customs, traditions, assertions in which a person believes and have them stably fixed in his/her consciousness and/or subconsciousness, etc." [6, p. 78].

Thus, a fixed attitude carries information and certain energy capacity, which reflects the degree of significance of information. Actually, the energy capacity (the degree of significance of information) activates the fixed attitude making its psychic and energy influence another internal psychic, activate it for the perception and transformation of information about what is necessary to do (what one wants to obtain). When a person has any psychic activated at a certain level of the psyche, the information about it is instantly transmitted everywhere. These levels of the human psyche, depending on the information (its content, psy-code), begin to function (to carry out psy-operations) contributing to the development of this psychic phenomenon. The activation of any internal psychic, as well as transformations in the psyche, occur as a result of the implementation of psy-operations in it, which represent the process of interaction of various external and internal or internally internal psychic, in connection with which the content of information and its energy capacity (degree of significance) is revealed, their transformation and the formation of a new psychic takes place. Actually a psy-program begins to be formed as a result of activation (increase in energy capacity) of a fixed attitude as the internal psychic [6, p. 78-79].

According to M. Variy, the human psyche functions on four levels - the unconscious, the subconscious, the conscious, and the superconscious one [7, p. 69-70]. The psycho-energy coming from the external environment interacts with the existing psychic, resulting in the accumulation of information and energy capacity in the human psyche. 


\section{Terletska Yuliana}

Consequently, the dissatisfaction of the needs that are in the surrounding environment, as the external psychic, transforms into the human psyche through the changes in mental processes, mental properties, and mental formations. And since mental processes, mental properties, and mental formations are the basics of the formation and functioning of psy-programs, then the change in their parameters leads to the changes in the effectiveness of the functioning of psy-programs.

Since the term "parameters of the psyche" is practically not used in psychological literature, we will explain its essence.

First of all, we shall refer to the Great Explanatory Dictionary of Modern Ukrainian to find out how the word "parameter" is interpreted. We see that this word has a significant number of definitions, including the following ones, “... 2. specialized. A value inherent in any object, device, phenomenon... 3. specialized. A variable value on which the value of another variable is dependent ... 6. figurative. A criterion, indicator, attribute, in relation to which an evaluation is carried out, by which something is characterized [8, p. 885].

Under the parameters of the psyche or its individual components, we understand the signs and indicators of variables of mental processes, mental properties, and mental formations, on which the effectiveness of the functioning of the psyche depends.

In the human psyche, starting from the prenatal period till the end of life, changes in parameters take place, that is, there are constant changes in the signs, indicators of the quality of such components of the human psyche as mental processes, mental properties, and mental formations, among which there are also psy-programs.

Consequently, under the mental parameters or parameters of the psyche one should understand the signs and indicators of a certain level of development, the degree of perfection (qualitative dimension) and intensity (quantitative dimension) of the functioning of the components of the psyche (which meet the criteria, indicators and characteristics that ensure the quality functioning of the psyche of a person in accordance with the person's age), as well as the actual components of mental processes (criteria and indicators of reception, perception, memory, thinking, imagination, will, emotional processes and states), mental properties (criteria and indicators of abilities, temperamental and characterological properties, memory capabilities, intellectual capabilities, etc.), mental formations 
(criteria and indicators of knowledge, skills, abilities, stereotypes, values orientations, motives, psychomotorics, speech, consciousness, self-consciousness, etc.).

And when the parameters of the psyche of an individual undergo a negative change, that is, instead of development there is a delay in development and even regression (for example, of components of sensations, perception, memory, thinking, imagination, will, emotions, feelings, etc.), positive properties are destroyed, while negative ones are built, motivation changes, there is a revision of values (the previous ones are rejected), the components of consciousness and self-consciousness, psy-programs, etc. change in the negative direction, then the behaviour of the person changes, the quality of this person's professional activities changes as well and so on.

For example, in the above-described approach towards the understanding of deprivation - the approach of impoverished environment - the developmental delay of children, the underdevelopment of the "action strategy", etc. occurs due to the fact that these individuals have not formed adequate for their age (in terms of quality) psychological processes, mental properties, and mental formations, which in its turn prevented the creation of effective psy-programs of live activities.

In this case, we are talking about malformation or underdevelopment of the parameters of their psyche, that is, about the imperfection of perception, operations and forms of thinking, knowledge, abilities, skills from various aspects of social interaction, which prevented the formation of adequate psy-programs of understanding and evaluation of social reality, analysis and synthesis, comparison and grouping of social phenomena, definition of the essence and course of social processes, etc., in accordance with age sociopsychic norms. This reaffirms our opinion that such children, in the first place, do not sufficiently form, develop the components of mental processes, mental properties, and mental formations in accordance with the age norms, which leads to a general decrease in the efficiency of functioning of the psy-programs, all psyche.

Since the surrounding environment (natural, sociocultural, spiritual, emotional, etc.) being the external psychic affects the development of the human psyche, personality in general, the lack of influence of some of their factors on them leads to the fact that some parameters of the components of mental processes, mental properties, and mental formations that lead together to the destructive functioning of the human psyche are simply not 


\section{Terletska Yuliana}

formed (not developed) or develop not fully, to a certain extent, partly or in a distorted way in the human psyche.

Thus, drawing on the above-mentioned statements, it can be stated that in the basis of psychological deprivation of a person, which arises from the dissatisfaction of the corresponding needs, there is the malformation and/or underdevelopment, and/or destruction of the parameters of mental processes, mental properties, and mental formations, which, in turn, leads to the destruction of the process of the operational and functional activity of the psyche.

The criteria for assessing the quality and effectiveness of the functioning of the psyche of an individual are those norms of development of the parameters of mental processes, mental properties, and mental formations, which ensure the effectiveness of the subject's vital activity at each age stage of his/her psycho-social development.

Therefore, according to the reflection of structural changes in the psyche, psychic deprivation of a person is a change in the parameters of mental processes, mental properties, and mental formations, which reduces the process of the operational and functional capacity of the psyche of the subject, that is, the quality, efficiency of its functioning, in accordance with the age norms of psycho-social development and norms of social life.

In general, from the point of view of the functional state of the psyche, psychic deprivation of a person is a stagnation, delay, inertia, rigidity, inhibition, failure of a person's psyche, in accordance with the age norms of psychosocial development and norms of social life, to perform the operative and functional activity adequately.

Proceeding from the notion of norm and deviation from it (non-normality), psychic deprivation of a person is an unnormalized process of functioning of the person's psyche, that is, the one that was not brought to the norm, was not normalized in accordance with the signs and indicators that reflect the psychosocial development that is inherent in every age psychosocial phase.

The very term "unnormalized", in accordance with the Great Explanatory Dictionary of the Modern Ukrainian language, means "... the one that was not normalized, brought to the norm, subordinated to the norm" [8, p. 768].

Deviation from the norm in the human psyche occurs due to the malformation or underdevelopment or destruction of certain parameters of the components of the human psyche, or their partial or complete absence in it. 


\section{Psychic deprivation in scientific terms}

Psychic deprivation of a person, in its essence, means a greater or lesser degree of the destructive process of functioning of its psyche, which was caused by the malformation, underdevelopment or destruction of certain mental parameters because of the subject's failure to satisfy certain needs necessary for its normal livelihood and development.

The capacity of the psyche is its active, adequate operational and functional activity that corresponds to the age development of the individual and the norms of the social culture, communication, behaviour, social activity, etc. Reduction of the capacity of a person's psyche manifests itself in the reduction of the effectiveness of the psyche's operational and functional activities. It is caused by the malformation, underdevelopment or destruction of certain parameters of the psyche, which emerge as a result of the person's dissatisfaction of certain needs necessary for the normal life activities and development.

The reason for the emergence of the psychic deprivation of a person lies in external conditions (external deprivation conditions), in which the person cannot satisfy the necessary needs, voluntarily deprives himself/herself of satisfying the needs that are necessary for the person's development and vital activities, or requires the satisfaction of such needs which cannot be satisfied or can be satisfied only under certain circumstances.

So, we can talk about psychic deprivation - more precisely, about the level of its development, which can be very high, high, above average, average, below average, low, and very low - only when certain parameters of mental processes (criteria and indicators of reception, perception, memory, thinking, imagination, will, emotional processes and states), mental properties (criteria and indicators of abilities, temperamental and characterological properties, memory capabilities, intellectual capabilities, etc.), mental formations (criteria and indicators of knowledge, skills, abilities, stereotypes, values orientations, motives, psychomotorics, speech, consciousness, self-consciousness, etc.) in the human psyche have not been completely formed (are absent), or have been partially formed (are underdeveloped), or are destroyed as a result of a total or partial dissatisfaction of needs, which in turn which in turn distorts, that is, makes to a greater or lesser extent the process of the operational-functional psyche activity and its psy-programs destructive.

When exploring the notions of deprivation and psychic deprivation, researchers also refer to the concepts of "deprivation mechanisms", 
"deprivation situation", as well as speak about different types of deprivation. Thus, J. Laugmeier and Z. Matejcek view the notion of "deprivation mechanism" as a process caused by the lack of satisfaction of the basic mental needs of a child, which modifies the structure of the child's personality in a special way. In a nutshell, the mechanism of "deprivation" is interpreted as a process that leads to deprivation [14, p. 22]. We cannot support this view, because the mechanism is an instrument, while the process is the dynamics of change: development, regression, transformation, etc.

Unlike the mechanisms of deprivation, the deprivation situation is interpreted as a life situation in which a person is not provided or is only partially provided with the possibility to satisfy the necessary needs.

Thus, on the example of the events of Holodomor, A. Masliuk identifies such mechanisms of deprivation as restrictions of food, religion, freedom of movement, information, traditions [20]. At the same time, he writes about deprivation situations, which include the economic policy of the totalitarian regime (creation of collective farms, excessive grain procurement, fiscal measures for the withdrawal of food), suppression of peasant resistance, agitation, restriction of movement of people, introduction of the "Law of Three Spikelets" and passport system [20, p. 67].

In our opinion, it is inappropriate to use the concept of "deprivation mechanism" in the interpretation of the abovementioned authors. It is more expedient to talk about a deprivation process, under which we understand parallel-sequential changes in the psyche of a person as a result of being in deprivation conditions.

Instead of the notion of "deprivation situation", it is advisable to introduce the concept of "deprivation conditions" and "form of deprivation". Under the notion of "deprivation conditions" one should understand the reality in which a person cannot satisfy some needs. Under the notion of "form of deprivation" one should understand the way of the person's existence in these deprivation conditions. Thus, the forms of deprivation can be as follows: full or partial, forced or voluntary isolation (imprisonment, isolation), disregard, objective or subjective restriction in satisfaction of certain needs, etc.

Consequently, deprivation process, deprivation conditions, and the forms of psychic deprivation - as the external psychic - directly affect mental processes, mental properties, and mental formations of a person, while 
their integral interaction causes certain mental states and also affects the functioning of the person's psy-programs.

Psychological deprivation can be explicit or implicit (disguised).

The explicit psychological deprivation is obvious: a person's stay in the conditions of social isolation, prolonged solitude, upbringing of a child in an orphanage, etc.

The implicit (disguised) psychic deprivation is not so obvious. It emerges within externally favourable conditions, which, however, do not provide the opportunity to satisfy the essential needs of a person. Thus, J. Bowlby writes about the disguised deprivation as of a partial one, which can be observed where there was no direct separation between the mother and the child, but their relationship for some reason is unsatisfactory for the child [10].

In terms of duration, any deprivation can be short-term, protracted, or long-lasting.

As a result of the scientific and theoretical, systematic and analytical search, we came to the conclusion that psychic deprivation is divided into the following types: psycho-sensory, psycho-emotional, psycho-physiological, psycho-cognitive, psycho-motor, psycho-social, psycho-economic, psycho-cultural, psycho-spiritual, and psycho-sexual. Each of the types can be furtherly subdivided, which we will dwell upon in further research.

However, in pure form, each type of deprivation can be identified only experimentally, because in life they exist in a complex interweaving.

\section{Conclusions}

The analysis of foreign and domestic literature on the problems of deprivation and psychic deprivation shows that today there is no uniformed approach to the definition of their essence and content, and the semantics of these concepts often depends on the conceptual and theoretical position of the author. At the same time, two essential features of the researchers' positions were revealed. The first feature is that one part of the researchers view the concept of "deprivation" in the conceptual plan of psychological phenomenology as the main, determinant concept; and the second feature is the fact that it is actually psychic deprivation that is understood by deprivation. At the same time, definition of the essence of deprivation and psychic deprivation is narrowed down to their interpretation as either a mental state, or to 


\section{Terletska Yuliana}

the causes of their occurrence, and this interpretation is, in fact, equated to these causes, or to the consequences to which they lead.

According to the relevant features, we have identified and substantiated seven approaches to the understanding and interpretation of deprivation and psychic deprivation. Namely, these are static psycho-permanent approach, deficiently-losing one, of impoverished environment, deviant, negatively deterministic, of social exclusion, and psychic and emotional approach.

In order to reveal the essence and content of psychic deprivation, we used a psychic and energetic functional approach, highlighted in the energy conception of the psyche and psychic by M. Variy. It is proved that: 1) in its essence, psychic deprivation of a person means to a greater or lesser extent the destructive process of functioning of its psyche a process that was caused by the malformation, underdevelopment or destruction of certain mental parameters because of the subject's failure to satisfy certain needs necessary for normal livelihood and development; 2) with regard to the reflection of structural changes in the psyche, psychic deprivation of a person is a change in the parameters of mental processes, mental properties, and mental formations, which reduces the process of the operational and functional capacity of the psyche of the subject, that is, the quality, effectiveness of its functioning, in accordance with the age norms of psychosocial development and norms of social life; 3 ) with regard to the functional state of the psyche, psychic deprivation of man is manifested as stagnation, delay, inertia, rigidity, inhibition, failure of a person's psyche, in accordance with the age norms of psychosocial development, to adequately perform the operative and functional activity; 4) with regard to the norm and deviation from it (non-normality), psychic deprivation of a person is an unnormalized process of functioning of the person's psyche, that is, the one that was not brought to the norm, was not normalized in accordance with the signs and indicators that reflect the psychosocial development that is inherent in every age psychosocial phase.

It is established that the reason for the emergence of the psychic deprivation of a person is the external deprivation conditions in which the person cannot satisfy the necessary needs, as well as the internal factors due to which the person voluntarily deprives himself/herself of satisfying the needs that are necessary for the person's development and vital activities, or requires the satisfaction of such needs which cannot be satisfied or can be satisfied only under certain circumstances. 


\section{Psychic deprivation in scientific terms}

It is discovered that deprivation conditions are the reality in which a person cannot satisfy certain needs; deprivation process means parallel-sequential changes in the psyche of a person as a result of being in deprivation conditions; the form of deprivation is the way of the person's existence in these deprivation conditions.

Psychic deprivation can be explicit or implicit (disguised).

On the basis of the results of the scientific and theoretical, systematic and analytical search, we came to the conclusion that psychic deprivation is divided into the following types: psycho-sensory, psycho-emotional, psycho-physiological, psycho-cognitive, psycho-motor, psycho-social, psycho-economic, psycho-cultural, psycho-spiritual, and psycho-sexual.

Such kinds of psychic deprivation as psycho-sensory, psycho-emotional, psychophysiological, psycho-cognitive, psycho-motor, psychosocial, psycho-economic, psycho-cultural, psycho-spiritual, and psycho-sexual as well as their influence on the development, behavior and human activity need further scientific development.

\section{References:}

1. Alekseenkova E.G. (2009) Lychnost v uslovyiakh psykhycheskoi depryvatsyy: uchebnoe posobye [Personality in the conditions of psychological deprivation: study guide] / E.G. Alekseenkova. St. Petersburg: Piter. (in Russian).

2. Berne E. (1992) Yhry v kotorye yhrayut lyudy. Psykholohyya chelovecheskykh vzaymootnoshenyy. [Games people play. The Psychology of human relationships. People who play games. Psychology of human fate. Minsk : PRAMEB. (in Russian).

3. Meshcheryakov B. G. (ed.). (2007). Bol'shoy psykholohycheskyy slovar'. [Great Psychological Dictionary]. St. Petersburg: Prime - YEVROZNAK. (in Russian).

4. Variy M.Y. (2009). Enerhetychna kontseptsiia psykhiky i psykhichnoho: monohrafiia. [Energy conception of the psyche and the psychic: monograph]. Kyyiv : Centre for Educational Literature. (in Ukrainian).

5. Variy M.Y. (2014). Zahalna psykholohiia: pidruchnyk. Lviv. derzh. un-t bezpeky zhyttiediialnosti. 4-te vyd., vyprav. i dopovn. [General psychology: a textbook / M. Y. Variy; Lviv State University of Life Safety. 4th edition, correc. and supplem.]. Kyyiv: Znannia. (in Ukrainian).

6. Variy M.Y. (2017). Psi-prohramy-znariaddia utvoren i peretvoren u psykhitsi liudyny. [Psy-programs as an instrument of formations and transformations in the human psyche]. Science and Education a New Dimension. Pedagogy and Psychology, V (62), Issue: 142, P. 77-81. (in Hungary).

7. Variy M.Y. (2017). Psykhika liudyny u psykhoenerhetychnii kontseptsii. [Human psyche in the psychic and energetic conception]. Science and Education 


\section{Terletska Yuliana}

a New Dimension. Pedagogy and Psychology. V (54), Issue: 126. P. 65-71. (in Hungary).

8. Busel V.T. (ed.). (2007). Velykyi tlumachnyi slovnyk ukrainskoi movy. [Great explanatory dictionary of the Ukrainian language]. Kyyiv; Irpin: "Perun". (in Ukrainian).

9. Hoshovskyi O.Ya. (1995). Stanovlennia obrazu v pidlitkiv shkoly-internatu v umovakh depryvatsii batkivskoho vplyvu: dys. ... kand. psykhol. nauk. [Formation of the self-image of teenagers in orphan boarding schools in the conditions of deprivation of parental influence: thesis for a candidate degree in psychology: 19.00.07]. Kyyiv. 177 p. (in Ukrainian).

10. Dmitriev Yu.A. (2007). Penytentsyarnaya psykholohyya. [Penitentiary psychology]. Rostov-on-Don: Fenix, 681 p. (in Russian).

11. Yerzhabkova B. (2003). Vybrani pytannia sotsialnoi pedahohiky. [Selected issues of social pedagogy]. Drohobych: Vymir, 364 p. (in Ukrainian).

12. Karpenko L.A. (ed.). (1985). Kratkyy psykholohycheskyy slovar'. [Concise Psychological Dictionary]. Moscow: Politizdat, 431 p. (in Russian).

13. Kun D. (2005). Osnovy psykholohyy: Vse tayny povedenyya cheloveka. [Essentials of psychology: all secrets of human behaviour]. St. Petersburg: PrimeYEVROZNAK, 720 p. (in Russian).

14. Laugmeier J. (1984). Psykhycheskaya depryvatsyya $v$ detskom vozdaste. Psychological deprivation in childhood. Prague: Czechoslovak Socialist Republic: Avicenium. Medical publishing house, 334 p. (in Russian).

15. Levitov N.D. (1964). O psykhycheskykh sostoyanyyakh cheloveka. [On mental states of man]. Moscow: Prosveshchenie, 342 p. (in Russian).

16. Levitov N.D. (2004). O psykhycheskykh sostoyanyyakh cheloveka. [Determination of the mental state]. Psychology of states. Reader. Moscow: PER SE; St. Petersburg: Rech, pp. 31-34. (in Russian).

17. Mukhina V.S. (ed.). (1991). Lyshennye rodytel'skoho popechytel'stva: khrestomatyya, ucheb. posob. [Deprivation of parental guardianship: textbook]. Moscow: Prosveshcheniye, 223 p. (in Russian).

18. Maksymenko S.D. (2006). Heneza zdiisnennia osobystosti. [Genesis of personality realization]. Kyyiv: "KMM" publishing house, 240 p. (in Ukrainian).

19. Maksymenko S.D. (2002). Rozvytok psykhiky v ontohenezi: $v 2$ t. [Development of the psyche in ontogenesis: in 2 volumes]. Kyyiv: Forum, Vol. 1. 319 p. (in Ukrainian).

20. Masliuk A.M. (2010). Osoblyvosti perezhyvannia liudynoiu dovhotryvaloi fiziolohichnoi depryvatsii (na materialakh holodomoriv v Ukraini): dys. ... kand. psykh. nauk: 19.00.01. [Peculiarities of experiencing a long-term physiological deprivation (on materials of famines in Ukraine): thesis for a candidate degree in psychology: 19.00.01]. Kyiv, 231 p. (in Ukrainian).

21. Prikhozhan A.M. (1990). Dety bez semy. [Children without family]. Moscow: Pedagogika, 160 p. (in Russian).

22. Corsini R. (ed.). (2006). Psykholohycheskaya entsyklopedyya. [Psychological Encyclopedia]. St. Petersburg: Piter, 1096 p. (in Russian).

23. Stepanov O.M. (ed.). (2006). Psykholohichna entsyklopediia. [Psychological Encyclopedia]. Kyiv: "Akademvydav”, 424 p. (in Ukrainian). 
24. Reber A. (2001). Depryvatsyya. Bol'shoy tolkovyy psykholohycheskyy slo$v a r '$. [Deprivation. Great explanatory psychological dictionary]. Moscow: VecheACT. V. 1. P. 226. (in Russian).

25. Rogov E.I. (2003). Nastol'naya knyha praktycheskoho psykholoha: ucheb. posob: $v 2 \mathrm{kn}$. [Table book of a practical psychologist: a textbook: in 2 books]. Moscow: Publishing House VLADOS, Book 1. 384 p. (in Russian).

26. Davydov V.V. (ed.). (1993). Rossyyskaya pedahohycheskaya entsyklopedyya: $v 2 t$. [Russian Pedagogical Encyclopedia: in 2 volumes]. Moscow: BRE, 528 p. (in Russian).

27. Sergiyenko E.A. (1990). Problema psykhycheskoho razvytyya: nekotorue ostrue voprosu y puty ykh reshenyya. [The problem of mental development: some critical problems and the ways of their solution]. Psychological Journa, vol. II., no. 5, pp. 150-160 (in Russian).

28. Fedenko N.F. (1981). Obshchye voprosy voennoy psykholohyy. Osnovy voennoy psykholohyy y pedahohyky: ucheb. posob. [General questions of military psychology. Fundamentals of Military Psychology and Pedagogy: a textbook]. Moscow: Voenizdat, pp. 7-32. (in Russian).

29. Spitz R.A. (2000). Pervuy hod zhyzny: psykhoanalytycheskoe yssledovanye normal'noho y otklonyayushchehosya razvytyya obektnykh otnoshenyy. [The first year of life: A psychoanalytic study of normal and deviant development of object relations]. Moscow: Gerrus, 384 pp. (in Russian).

30. Yadvirshis L.A. (1997). Preodolenye depryvatsyy u detey $v$ deyatel'nosty pedahoha. [Overcoming the deprivation of children in the activities of teachers]. Bryansk: BIPKRO, 54 p. (in Russian). 